\title{
PERUBAHAN BIROKRASI PEMERINTAHAN DAERAH KEWEDANAAN RAWAS 1943-1950
}

\author{
Supian Ramli \\ Departemen Sejarah, Seni dan Arkeologi Universitas Jambi \\ supianramli@unja.ac.id \\ Lagut Bakaruddin \\ Mahasiswa Program Studi Ilmu Sejarah, Universitas Jambi \\ lagutbakaruddin@gmail.com
}

\section{Abstract}

During the Japanese government, the bureaucracy during the Dutch East Indies government was still carried out, but only the name changed. Rawas, which is an Ondeer Afdeelig area, has changed its status to Gun Rawas, but in the near future the Japanese government will form a district level area, namely Musi Ulu Rawas . The aim of the Japanese research is to describe the changes in the rawas government bureaucracy from the occupation era to the present. This study uses a historical method which consists of several stages such as Heuristics, Criticism, Interpretation and Historiography. The results of this study can describe the changes in the local government system of Rawas and eventually it became Musi Ulu Rawas Regency in its development into Musi Rawas Regency.

Keywords: Bureaucracy, Government, Rawas

\begin{abstract}
Abstrak
Pada masa pemerintahan Jepang birokrasi pada masa pemerintahan Hindia Belanda tetap dijalankan namun namanya saja yang berubah. Rawas yang merupakan wiilayah Ondeer Afdeelig statusnya berubah menjadi Gun Rawas namun dalam waktu dekat pemerintahan Jepang membentuk daerah setingkat Kabupaten yakni Musi Ulu Rawas.

Tujuan dari penelitian adalah menggambarkan perubahan birokrasi pemerintahan rawas dari zaman pendudukan jepang hingga saat ini. Penelitian ini mengunakan metode historis yang terdiri dari beberapa tahapan seperti Heuristik, Kritik, Interpretasi dan Historiografi. Hasil dari penelitian ini dapat mengambarkan perubahan sistem pemerintahan daerah Rawas dan akhirnya menjadi Kabupaten Musi Ulu Rawas dalam perkembanganya menjadi Kabupaten Musi Rawas.
\end{abstract}

Kata Kunci: birokrasi, pemerintahan, Rawas

\section{Pendahuluan}

Pada tanggal 7 Desember 1941 Jepang mengadakan serangan terhadap pangkalan angkatan laut Amerika Serikat di Pearl Harbour, Hawai. Pasca kejadin tersebut pemerintahan Hindia Belanda mengumumkan perang terhadap Jepang . Pada tanggal 25 Desember 1941 jepang mulai melancarkan seranganya dan berhasil menduduki 
Hongkong kemudian melanjutkan serangan dan berhasil menyerbu Malaysia. Inggris yang mempertahankan mati-matian Malaysia akhirnya lumpuh pada bulan Februari 1942. Sasaran berikutnya di tahun yang sama yakni Birma kemudian Flipina. Dalam seranganya ke Hindia Belanda (Indonesia) Jepang dikatakan memperoleh kemajuan yang sangat baik. Jepang pertama kali menduduki Tarakan 11 Januari 1942, kemudian Ibukota Keresidenan Palembang jatuh ke tangan Jepang pada tanggal 14 Januari 1942. Jepang kemudian melanjutkan seranga-serangan kepada kota-kota penting di Hindia Belanda seperti Balikpapan, Pontianak dan Bali. ${ }^{1}$

Detik-detik Jatuhnya Hindia Belanda ke tanggan Jepang dimulai dengan penyerbuan ke Kota Bandung 1 Maret 1942 keesokan harinya lapangan terbang Subang pada tanggal 3 Maret 1942 tantara Belanda dipukul mundur. Menyusul pada tanggal 5 Maret 1942 tantara Jepang bergerak ke Kalijati. Akhirnya pada tanggal 8 Maret 1942 Pemerintahan Hindia Belanda menyatakan menyerah tanpa syarat pada Jepang. ${ }^{2}$ Pasca pristiwa Kalijati maka seluruh pemerintahan Hindia Belanda kembali dimiliki oleh Jepang yang dikenal dengan pemerintahan Militer Jepang.

Dengan seluruh wilayah Hindia Belanda dikuasai Jepang termasuk wilayah Keresidenan Palembang. Salah satu daerah potensial pada masa Jepang yaitu Rawas. Kajian Sejarah Rawas pada masa Jepang sangat jarang dilirik oleh para penulis Sejarah. Berbicara birokrasi Pemerintahan Jepang di Rawas sangat unik untuk dikaji dan memiliki nilai sejarah yang tinggi. Rawas merupakan daerah yang berada di bagian Barat Palembang. Secara umum diketahui bahwa birokarasi pemerintahan Jepang tetap mengikuti Hindia Belanda, namun demikian terdapat perubahan yang segnitifikan terutama dalam penamaan dan pembagian adminstarasinya.maka untuk melihat birokrasi di daerah Rawas masa Jepang penulis memberi judul yakni "Perubuhan Birokrasi Pemerintahan Daerah Rawas Masa 1943-1950"

Setiap penelitian sejarah memiliki batasan masalah yakni batasan temporal dan batasan spasial. Adapun batasan temporal peneitian ini yakni dimulai tahun 1943 alasan mengambil tahun ini karena pada tahun ini pemerintahan Jepang membentuk sebuah Pemerintahan setingkat Kabupaten (Bunsyu) dalam bahasa Belanda disebut Afdeeling yakni Bunsyu Musi Ulu Rawas yang disebut Bunsyu Ulu Rawas karena Bunsyu ini merupakan gabungan dari Gun (Kewedanaan) Musi Ulu dan Gun (Kewedanaan) Rawas dan pada tahun 1943 juga akhirnya diputuskan sebagai tahun jadinya Kabupaten Musi Rawas. Kemudian batas akhirnya yakni tahun 1950 alasan mengambil tahun karena pada tahun Pemerintahan Kabupaten Musi Ulu Rawas berganti nama Menjadi Kabupaten

1 Adi Sudirman. Sejarah Lengkap Indonesia Dari Era Klasik Sampai Sekarang.(Yokyakarta: DivaPress .2014). h. 275-276

2 Ibid, h. 278 
Musi Rawas di Provinsi Dati I Sumatera Selatan pasca dibubarknya Negara Sumatera Selatan.

\section{Metode}

Penelitian ini mengunakan metode penelitian Historis atau penelitian sejarah. Yang di maksud penelitian sejarah adalah penelitian yang mengunakan jejak masa lalu. Baik itu dari sumber tertulis buku, jurnal dan sejenisnya, wawancara maupun rekam peningalan benda masa lalu. Menurut Kuntowijoyo ada lima tahapan dalam penelitian sejarah yang pertama pemilihan topik, pengumpulan sumber (Heuristik), Verifikasi (Kritik), Panafsiran (Interpretasi) dan yang terakhir penulisan atau Historiografi. Adapun tahap-tahapanya sebagai berikut:

1. Heuristik

Heuristik dapat diartikan sebagai pengumpulan. Yang dimaksud pengumpulan adalah sebuah kegiatan mencari sumber sejarah dan jejak pada masa lampau. ${ }^{4}$ Adapun sumber yang penulis dapatkan adalah karangan dari Tim pemerintahan Kabupaten Musi Rawas pada tahun 2002 dan bebrapa karangan sejarawan bumi silampari Suwandi Syam yang penulis dapatkan dari Museum Subkoss Kota Lubuklinggau.

2. Kritik

Yang dimaksud dengan kritik adalah cara yang dilakukan oleh penulis sehjarah untuk mendaptkan keaslian sumber. Kritik sumber dibedakan menjadi dua yakni internal (Dalam) dan eksternal (Luar).

3. Interpretasi

Interpretasi atau diistilahkan panafsiran. Penafsiran sangat erat kaitanya dengan pandangan penulis, latar belakang, pola pikir, dan lain-lain. Interpretasi dapat dikatan sangat rawan subjektif tergantug bagaiamnakah penulisnya. Namun demikian untuk menimalisir hal tersebut maka dapat diatasi dengan metodologi sejarah. ${ }^{5}$

4. Historiografi.

Tahapan terakhir dalam penelitian sejarah yakni Historiografi atau penulisan sejarah.

\footnotetext{
${ }^{3}$ Kuntowijoyo. Pengantar Ilmu Sejarah.( Jakarta: Benteng Pustaka. 2005).h. 90

${ }^{4}$ Yulia Resha Pertiwi. Sejarah Pemekaran Kabupaten Tanjung Jabung Timur 1999-2010. Skripsi. Departemen Sejarah Fakultas Ilmu Budaya Universitas Jambi. 2017. h. 14

${ }^{5}$ Suhartono W Pranoto. Teori dan Metodologi Sejarah. (Jakarta: Graha Ilmu. 2014). h. 55
} 


\section{Pembahasan}

\section{Pemerintahan Daerah Rawas Masa Pemerintahan Jepang}

Pasca pemerintahan Jepang menguasai Hindia Belanda melalui perjanjian Kalijati 8 Maret 1942 . Jepang membentuk pemerintahan Pendudukan Militer. Berbeda dengan Hindia Belanda yang hanya terdapat satu pemerintahan Sipil yakni Gubernur Jendral. Pada masa pemerintahan Jepang ini Indonesia dibagi menjadi tiga pemerintahan Militer yakni:

1. Pemerintahan Militer Angkatan Darat (Tantara ke- 25) untuk daerah Sumatera dan sekitarnya yang berpusat di Kota Buktitinggi.

2. Pemerintahan Militer Angkatan Darat (Tantara ke 16) untuk daerah Jawa, Madura dan sekitarnya yang berpusat di Jakarta

3. Pemerintahan Militer Angkatan Laut (Armada Selatan ke II) untuk daerah Sulawesi, Borneo (Kalimantan), Kepulauan Maluku dan sekitarnya yang berpusat di Ujung Pandang (Makasar). ${ }^{6}$

Menurut Undang-undang No. 27 Tahun 1942 atau dalam tahun Jepang 2062. Tentang perauban pemerinathan dengan susuanan sebagai berikut: Keresidenan berubah menajdi Syu, Kabupaten berubah menjadi Bunsyu, Kota Prja beruah menjadi Syi, Kewedanaan berubah menjadi Gun Kecamatan atau Marga berubah menajdi Son pemerintahan dusun berubah menjadi $\mathrm{Ku}^{7}$

Pulau sumatera sama seperti masa Hindia Belanda dibagimenjadi sepuluh Syu yakni: Syu Palembang, Aceh, Sumatera Timur, Tapanuli, Lampung, Bengkulu, Bangka Belitung, Jambi dan Riau. Setiap Syu dipimpin oleh Syucokan. Pulau Sumatera yang sangat luas membuat pemerintahan Jepang kesulitan dalam pengontrolan maka dibentuklah tiga gubernur daerah yakni Sumatera Selatan, Sumatera Tengah dan Sumatera Utara. Gubernur daerah ini bertugas mengontrol dan mengkoordinasikan syu yang ada di pulau Sumatera. ${ }^{8}$

Perubahan yang terjadi oleh Pemerintahan Militer Jepang tidak terkecuali juga di daerah Rawas. Pada masa Hindia Belanda Rawas merupakan pemerintahan Afdeeling di Bawah Keresidenan Palembang. Kemudian pada masa Jepang terjadi berbagai perubahan. Pada tahun 1942 Jepang sudah mulai masuk ke Lubuklinggau dan mengambil alih pemerintahan Hindia Belanda yang sudah bertekuk lutut. Kemudian dalam tahun yang sama terjadilah penyerahan kekuasaan wilayah daerah Ondeer Afdeeling Rawas dan Musi Ulu kepada pemerintahan Militer Jepang. Dengan demikian semua

\footnotetext{
${ }^{6}$ Marwati dan Nugroho. Sejarah Nasional Indonesia VI. (Jakarta: Balai Pustaka. 2011). h. 20

7 Adi Sudirman, Op.Cit. h. 287

${ }^{8}$ Marwati dan Nugroho. Op.Cit. h. 21
} 
instansi baik di Rawas maupun di Musi Ulu tetap dijalankan sebaimana semestinya namun nama dan peimpinan ikut berubah sesuai dengan pemerintahan Jepang.'

Rawas yang semula merupakan Ondeer Afdeeling dibawah pemerintahan Afdeeling Palembangsche Boven Landen yang beribukota di Lahat. Kemdudian pada masa Jepang dibentuklah Bunsyu (Kabupaten) daerah setingkat Afdeeling yang bernama Bunsyu Musi Kami Rawas. Bunsyu atau Kabupaten ini dibentuk dengan dua daerah Gun (Ondeer Afdeeling) yakni Gun Musi Ulu dan Gun Rawas. Maka dari itu dikenal dengan Bunsyu Musi Kami Rawas. Kami dalam bahasa Jepang berarti Ulu. Bunsyu Musi Kami Rawas dipimpin oleh seorang bupati atau dalam bahasa Jepang disebut Bunsyuco yang bernama Kato. Dalam waktu yang singkat buapati (Bunsyuko) Musi Ulu Rawas diganti dengan yang baru oleh pemerintahan Jepang yang bernama Swada. Berbagai pergolokan masyrakat yang mulai tampak terang-terangan menantang pemerintahan Jepang. Jepang berbuat sesuatu dengan mengangkat wakil Bupati dari bumi Musi Ulu Rawas yakni Raden Ahmad Abusamah. Dalam bahasa Jepang disebut Bunsyuco Dairi (Wakil Bupati). ${ }^{10}$

Gun Rawas yang beribukota di Surulangun pada masa Pemerinthan Jepang masih terdapat pemerintahan Marga dalam bahasa Jepangnya disebut Son. Secara hirakis kedudukan marga dibawah pemerintahan Gun Rawas. Daerah Son (marga) dikepalai oleh seorang depati atau Pesirah. Adapun Son yang terdapat pada daerah Gun Rawas adalah sebagai berikut.
a. Son Ulu Rawas
b. Son Suka Pindah Ulu
c. Son Suka Pindah Tengah
d. Son Suka Pindah Ilir
e. Son Muara Rupit
f. Son Rupit Ilir
g. Son Rupit Dalam
h. Son Rupit Tengah

Pemerintahan dusun berubah menajadi Ki dan setiap Syu (Marga) terdiri dari beberapa Ki (Dusun). ${ }^{11}$

\footnotetext{
9 Pemerintahan Kabupaten Musi Rawas. Sejarah dan Peranan Subkoss Komandemen Sumatera Selatan Dalam Perjuangan Rakyat Musi Rawas 1945-1950. (Lubuklingau. 2002). h. 42

${ }^{10}$ Pemerintahan Kabupaten Musi Rawas.Ibid. h. 53

11 Suprinyanto. Pelayaran dan Perdagangan di Pelabuban Palembang. (Yokayakarta: Ombak 2013). h. 45
} 


\section{Pemerintahan Daerah Rawas Pasca Indonesia Merdeka}

Jepang mengalamai kekalahan besar dalam perang Asia Timur Rusia mengumumkan perang terhadap Jepang Jepang Akhirnya mengalami kekalahan demi kekalahan. Sehingga pada tanggal 7 Agustus 1945 Jepang membentuk PPKI (Panitia Persiapan Kemerdekaan Indonesia). Perjuangan demi perjuangan yang dilakukan oleh bangsa Indonesia dalam menyusun kemerdekaan Indonesia Akhirnya pada tanggal 17 Agustus 1945 teks proklamasi dikumadangkan di Pegangsaan Timur no 56 Jakarta. Dengan dibacanya teks proklamasi dengan ini Indonesia telah merdeka dan terlepas dari penjajahan Jepang ataupun Belanda. ${ }^{12}$

Pasca Kemerdekaan melalui sidang PPKI menetapkan Indonesia menjadi 8 Propinsi yakni Sumatera, Jawa Barat, Jawa Tengah, Jawa Timur, Kalimantan, Sunda Kecil, Sulawesi dan Maluku. Sumatera yang dijadikan satu propinsi yang dikepalai oleh seorang Gubernur (Mangkubumi) Tengku Moh Hasan dan bantu oleh tiga wakil mangkubumi (wakil gubernur). Masing-masing mangkubumi itu menempatai Sumatera Utara (Medan), Sumatera Tengah (Bukittinggi) dan Sumatera Selatan (Palembang). Ibukota Sumatera berada di Kota Medan Keresidenan Sumatera Timur. ${ }^{13}$

Berita proklamasi Kemerdekaan akhirnya disiarkan di Keresidenan Palembang dan berbagai Kewedanaan. Melalui Radio Palembang akhirnya berita proklamasi sampai kepada masyrakat dari berbagai lapisan di Keresidenan Palembang. Rawas yang merupakan daerah Syu Palembang dan Pemerintahan Bunsyu Musi Ulu Rawas pada tangaal 18 Agustus terjadilah pengambilan alih kekuasaan dari tangan Jepang. Bendera merah putih berkibaran di Bunsyu Musi Ulu Rawas Kota Lubuklinggau. Kewedanaan Rawas secara serentak pada sore hari mengibarkan bendera merah putih di halaman kantor wedana Raden Ahmad Amin di Ibukota Kewedanaan (Gun) Rawas. Selanjutnya disambut oleh marga-marga di Kewedanaan Rawas. Pasca Indonesia merdeka keadaan wilayah Musi Ulu dan Rawas tidak mengalami perubahan hanya nama nya saja yang berubah misalkan Gun Rawas menjadi Kewedanaan Rawas Bunsyu Musi Kami Rawas menjadi Kabupaten Musi Ulu Rawas. Sebagai kepala pemerintahan Kabupaten Musi Ulu Rawas ditetapkan bupati Raden Ahmad Abusamah. ${ }^{14}$

Pada tanggal 17-19 April 1946 Dewan perwakilan Rakyat Sumatera mengadakan rapat di Bukittinggi dewan perwakilan Rakyat Sumatera membagi Propinsi Sumatera menjadi tiga propinsi yakni Sumatera Selatan, Sumatera Selatan dan Sumatera Tengah. ${ }^{15}$ Propinsi Sumatera Selatan yang beribukota di palembang membawahi 4 Keresidenan

\footnotetext{
12 Musyrifah Sunanto. Sejarah Peradaban Islam.( Jakarta: PT Raja Grafindo Persada. 2012). Hlm 48

13 The Liang Gie. Pertumbuban Pemerintahan Daerah di Negara Republik Indonesia Jilid 1. (Yokayakarta: Liberty. 1993). h. 41-42

${ }^{14}$ Pemerintahan Kabupaten Musi Rawas, Op, cit. h. 67-69

15 Lindayanti, dkk. Menyibak Sejarah Tanah Pilih Pusako Batuah. (Jambi: Badan Arsip dan Dokumentasi Kota Jambi. 2014). h. 97
} 
yakni Palembang, Bangka Belitung, Bengkulu dan Lampung. Keresidenan Palembang sendiri merupakan Syu Palembang Pada masa Jepang.

Padat tanggal 30 Agustus 1948 terbentukah negara Sumatera Selatan (NSS) buat Belanda untuk memcah belah Negara Kesatuan Negara Republik Indonesia. Namun perlu digaris bawahi tidak semua daerah di Keresidenan paelmbang menjadi bagian dari Negara Summatera Selatan. Salah satunya Adalah Kewedanaan Rawas. Kewedanaan Rawas tetap menjadi bagian NKRI dibawah pemerintahan Propinsi Sumatera Selatan yang berpindah Ibukota ke Lubuklinggau. Selain Rawas ada bebrapa daerah seperti Musi Ulu, Lematang, Palembang Selatan dan Pasemah ${ }^{16}$

Pada tahun 1950 Gubernur Sumsel mengeluarkan ketetapan nomor Gb/100/1950 membentuk 6 Kabupaten di Keresidenan Paelmbang yakni

1. Musi Rawas

2. Muara Enim

3. Lahat

4. Ogan Komering Ulu

5. Ogan Komering Ilir

6. Palembang-Musi Banyuasin

Dalam ketetapan ini Kabupaten Musi Ulu Rawas berubah menjadi Kabupaten Musi Rawas. ${ }^{17}$ Kewedanaan Rawas yang merupakan bagian dari Kabupaten Musi Rawas yang beribukota di Lubuklinggau. Kewedanaan Rawas beribukota di Surulangun dibentuklah tiga Kecamatan yakni:

a. Kecamatan Rawas Ulu yang beribukota di Surulangun

b. Kecamatan Rupit yang beribukota di Muara Rupit

c. Rawas Ilir yang beribukota di Bingin Teluk

Pemerintahan Kewedanaan Rawas masih mempertahankan Pemerintahan tradisional marga. Pemerintahan Marga lasngsung dibawah pemerintahan Kecamatan. Adapun pembagianya sebagai berikut:

1) Kecamatan Rawas Ulu membawahi dua Marga:

a) Marga Ulu Rawas

b) Marga Suka Pindah Ulu

2) Kecamatan Rupit membawahi 4 Pemerintahan Marga:

a) Marga Muara Rupit

b) Marga Rupit Ilir

c) Marga Rupit Tengah

d) Marga Rupit Dalam

${ }^{16}$ The Liang Gie. Op, Cit.

17 The Liang Lhe. Op.Cit. h. 194 
3) Kecamatan Rawas Ilir Membawahi 2 Marga:

a) Marga Suka Pindah Tengah

b) Marga Suka Pindah Ilir ${ }^{18}$

\section{Kesimpulan}

Rawas merupakan daerah yang terletak di bagian barat Keresidenan Paelmbang. Pasca dikuasai oleh pemerintahan Jepang Rawas dikenal dengan Gun Rawas dalam bahasa Indonesia dengan istilah Kewedanaan Rawas.sejak 20 April 1943 Jepang membentuk bunsyu setingkat Kabupaten di wilayah Musi Ulu dan Rawas dalam perkembanya disebut Bunsyu Musi Ulu Rawas (Kabupaten Musi Ulu Rawas). Berbagai kebijakan sejak masa Jepang seperti marga di ganti nama menjadi son. Gun atau Kewedanaan Rawas terdiri dari 8 pemerintahan Marga yakni Ulu Rawas, Suka Pindah Ulu, Suka Pindah Tengah, Suka Pindah Ilir, Muara Rupit, Rupit Dalam, Rupit Tengah, dan Rupit Dalam.

Pasca Indonesia merdeka Rawas tetap bernama Kewedanaan Rawas dibawah pemerintahan Keresidenan Palembang Propinsi Sumatera Selatan. Dalam bebrapa waktu Bunsyu Musi Ulu Rawas berubaha mejadi Kabupaten Musi Ulu Rawas dengan Raden Abusamah sebagai bupati. Pasca Berdirinya Negara Sumatera Selatan. Rawas termasuk dari bebrapa daerah yang tidak dimasuki kedalam negara Sumatera Selatan. Pada taun 1950 pasca kembalinya NKRI Kabupaten Musi Ulu Rawas berubah nama menjadi Kabupaten Musi Rawa yang beribukota di Lubuklingau. Kewedanaan Rawas yang dibawah pemerintahan Kabupaten Musi Rawas terdiri dari 3 Kecamatan yakni Rawas Ulu, Rupit dan Rawas Ilir.

\section{Referensi}

Arsip. Dewan Presidium Kabuapten Rawas. Proposal Persiapan Kabupaten Rawas Tahun 2002 .

Adi Sudirman. Sejarah Lengkap Indonesia Dari Era Klasik Sampai Sekarang (Yogyakarta: Diva Press 2014).

Kuntowijoyo. Pengantar Ilmu Sejarah.( Jakarta: Benteng Pustaka. 2005).

Lindayanti, dkk. Menyibak Sejarah Tanah Pilih Pusako Batuah. (Jambi: Badan Arsip dan Dokumentasi Kota Jambi. 2014).

18 Dewan Presidium Kabuapten Rawas. Proposal Persiapan Kabupaten Rawas Tahun 2002. 
Pemerintahan Kabupaten Musi Rawas. Sejarah dan Peranan Subkoss Komandemen Sumatera Selatan Dalam Perjuangan Rakyat Musi Rawas 1945-1950. (Lubuklinggau. 2002).

Marwati dan Nugroho. Sejarah Nasional Indonesia VI. (Jakarta: Balai Pustaka. 2011).

Musyrifah Sunanto. Sejarah Peradaban Islam.( Jakarta: PT Raja Grafindo Persada. 2012.)

Suhartono W Pranoto. Teori dan Metodologi Sejarah. (Jakarta: Graha Ilmu. 2014)

Suprinyanto. Pelayaran dan Perdagangan di Pelabuban Palembang. (Yokayakarta: Ombak 2013).

The Liang Gie. Pertumbuhan Pemerintahan Daerah di Negara Republik Indonesia Jilid 1. (Yokayakarta: Liberty. 1993).

Yulia Resha Pertiwi. Sejarah Pemekaran Kabupaten Tanjung Jabung Timur 1999 2010. Skripsi. Departemen Sejarah Fakultas Ilmu Budaya Universitas Jambi. 2017. 